\title{
Isolated granulocytic sarcoma of the nasopharynx: a case report and review of the literature
}

\author{
Prakash Vishnu' \\ Ravindra Reddy Chuda ${ }^{2}$ \\ Dick G Hwang ${ }^{3}$ \\ David M Aboulafia ${ }^{1,4}$
}

'Floyd and Delores Jones Cancer Institute at Virginia Mason Medical Center, Seattle, WA, USA; ${ }^{2}$ Department of Internal Medicine, University of Kansas Medical Center, Kansas City, KS, USA; ${ }^{3}$ Department of Pathology, Virginia Mason Medical Center, ${ }^{4}$ Division of Hematology, University of Washington, Seattle, WA, USA
Correspondence: Prakash Vishnu Floyd and Delores Jones Cancer Institute, Virginia Mason Medical Center, II00 9th Avenue, Seattle,

WA 98101, USA

Tel +I 2062236193

Fax +I 2062232382

Email prakash.vishnu@vmmc.org
This article was published in the following Dove Press journal:

International Medical Case Reports Journal

16 December 2013

Number of times this article has been viewed

\begin{abstract}
Granulocytic sarcoma (GS) is a rare extramedullary manifestation of acute myeloid leukemia (AML). It may also represent blastic transformation of myelodysplastic syndromes or myeloproliferative neoplasms. Although usually seen in the context of advanced and poorly controlled disease, it may also present as the first manifestation of illness, without concurrent bone marrow or blood involvement. In the medical literature, chloroma and GS are terms that have been used interchangeably with myeloid sarcoma. GS usually manifests as soft tissue or bony masses in several extracranial sites, such as bone, periosteum, and lymph nodes; involvement of the head and neck region is uncommon. We report a case of a woman with insidious onset of progressive nasal congestion and diminished hearing who was diagnosed with an isolated GS of the nasopharynx. With involved field radiotherapy, she achieved a complete remission of 12-months duration before being diagnosed with overt AML. She has remained disease-free for greater than 18 months following induction and consolidation chemotherapy. Through a MEDLINE $^{\circledR} /$ PubMed $^{\circledR}$ search we identified an additional 13 cases of nasopharyngeal GS. The median age was 37 years (range 1 to 81 years). The cases were equally distributed among the sexes. The most common presenting symptoms were conductive hearing loss and sinonasal congestion. Isolated GS was identified in six cases, and the median time from diagnosis of GS to AML was 12 months (range 3 to 48 months). The treatment varied, but responses were seen in all the patients who received chemotherapy with or without radiotherapy.
\end{abstract}

Keywords: acute myeloid leukemia, myeloid sarcoma, chloroma, treatment

\section{Introduction}

Acute myeloid leukemia (AML) may occur in a variety of extramedullary (EM) tissues, with or without bone marrow disease. Two well-known EM manifestations of AML are granulocytic sarcoma (GS) and leukemia cutis. GS, also known as myeloid sarcoma or chloroma, is a rare EM tumor of immature myeloid cells. ${ }^{1}$ The high expression of myeloperoxidase (MPO) makes these tumors appear green hence, the name "chloroma" (from the Greek "chloros," meaning green). ${ }^{2}$ GS can develop de novo or concurrently with AML, myeloproliferative neoplasms (MPNs) or myelodysplastic syndromes (MDSs). ${ }^{1,3-6}$ Isolated GS defined by the absence of a history of AML, MDS, or MPN, and unremarkable blood and bone marrow analyses has been described, albeit sparsely. ${ }^{7-9} \mathrm{GS}$, most commonly see in the context of widespread and uncontrolled disease, may also be the first manifestation of AML, antedating it by months or years, or represent the initial manifestation of relapse in a patient previously treated for AML. ${ }^{10,11}$ The risk factors for GS include specific chromosomal abnormalities, such as translocations between chromosomes 8 and 21 (t[8;21]) and 
inversion of chromosome 16 (inv[16]), the expression of cell-surface markers (cluster of differentiation [CD]56, $\mathrm{CD} 2$, CD4, and CD7), and the French-American-British (FAB) classification M2, M4, and M5 leukemia subtypes. Additional risk factors include poor nutritional status, cellular immune dysfunction, high presenting leukocyte count, and decreased blast Auer rods. ${ }^{12}$ GS is slightly more common in men than in women (male to female ratio, 1.42:1). ${ }^{13}$ While various body sites have been associated with GS, the most common locations include soft tissue, bone, periosteum and the lymph nodes. ${ }^{9}{ }^{12}$ Here, we describe the case of a female with GS manifesting as a nasopharyngeal mass that was treated with radiation therapy, after which AML manifested 12 months later. We also review the literature of previously reported cases of nasopharyngeal GS and focus on the clinical presentation, diagnosis, and the treatment of this disorder.

\section{Case report}

A 63-year-old Caucasian female sought evaluation in the Otolaryngology clinic (Virginia Mason Medical Center, Seattle, WA, USA) due to decreased hearing in her left ear and progressive nasal congestion. Prior to that visit, she had been treated empirically for several months with various antibiotics and decongestants and briefly with intranasal steroids. Her chronic medical problems were notable for nonallergic rhinitis, hypertension, hyperlipidemia, and morbid obesity. Her general and cranial nerve exam were unremarkable, but she was identified as having conductive hearing loss due to a left middle ear effusion. On sinonasal endoscopy, an excoriated mass was also identified, involving the posterior nasopharynx and nasal turbinates. A biopsy of the mass revealed intermediate-sized blastic cells that stained positive for MPO, CD68 (dim), CD99, and CD117 (dim), consistent with involvement by GS (Figure 1). The results of the laboratory studies included a normal complete blood count $(\mathrm{CBC})$ as well as unremarkable serum chemistry and liver enzyme levels. A flow cytometry study of the circulating white cells was also unremarkable, as were the polymerase chain reaction (PCR) studies of peripheral blood for the breakpoint cluster region (BCR)-Abelson ( $A B L$ ) gene rearrangements and Janus kinase 2 (JAK-2) mutations. A bone marrow biopsy showed no evidence of AML or features of an MPN; normal trilineage hematopoiesis was present. A chromosome analyses showed an XX karyotype. An integrated whole body positron emission tomography-computed tomography (PET-CT) scan showed only modest inflammation in the nasopharynx (Figure 2). Because of her age and comorbid medical conditions, we elected to treat her GS with involved-field radiation therapy to the nasopharynx, 30 Gy delivered in 15 daily fractions. She

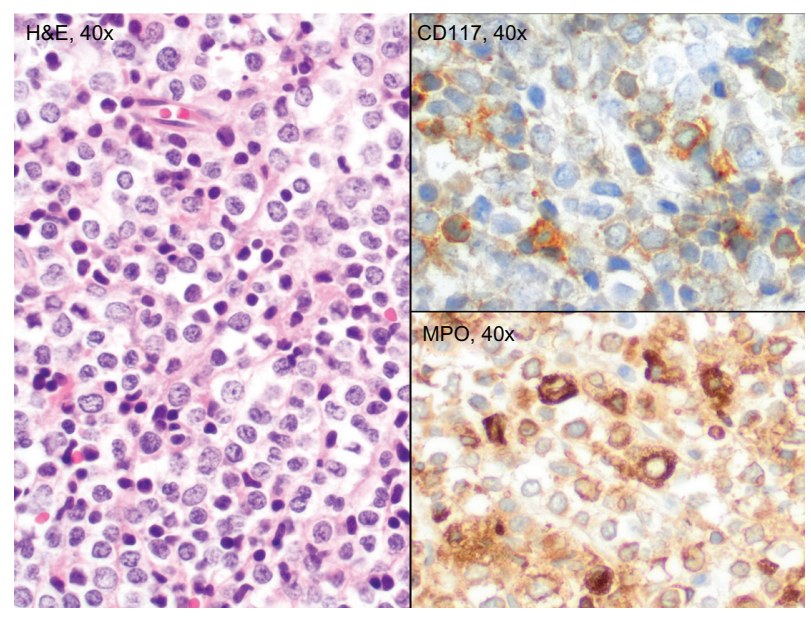

Figure I Biopsy of the nasopharyngeal mass, showing sheets of intermediate-sized blasts with round nuclei, dispersed chromatin, distinct nucleoli, and small amounts of cytoplasm. The tumor cells stained positive for myeloperoxidase and weakly for CDII7.

Abbreviation: CD, cluster of differentiation; MPO, myeloperoxidase; H\&E, hematoxylin and eosin.

tolerated the radiation therapy well, with alopecia involving the vertex of her scalp and mild mucositis, fatigue, and dysgeusia. Subsequently, she was monitored closely, with exams of her nasopharynx coupled with blood studies every 2 to 3 months. Twelve months after her initial diagnosis of isolated GS, the patient presented to clinic with fever and cough of a week's duration and complained of recrudescent fatigue and dyspnea on exertion. On exam, she appeared acutely ill, dehydrated, febrile, and diaphoretic, and with diminished breath sounds and crackles at the left lung base. A chest radiograph showed findings consistent with left lower lobe pneumonia. Her CBC consisted of a white blood count (WBC) of $11.8 \times 10^{9} / \mathrm{L}$ with $62 \%$ myeloid blasts, hematocrit of $23 \%$, and platelets of $117 \times 10^{9} / \mathrm{L}$. The flow cytometric analysis of peripheral blood revealed an abnormal population of blasts (CD45-dim) that expressed CD117 (moderate) and bright uniform CD33; this population comprised approximately $80 \%$ of the circulating WBCs. The tumor cells were negative for human leukocyte antigen (HLA)-DR, CD34, CD13, CD14, CD15, CD16, CD64, CD2, CD3, CD4, CD5, CD7, CD56, CD71, and CD38. The phenotype was similar to the phenotype of the myeloid blasts identified in her prior nasopharyngeal biopsy. Band karyotyping of the peripheral blood blasts showed normal (46, XX) cytogenetics. Induction chemotherapy was prescribed, consisting of cytarabine $\left(100 \mathrm{mg} / \mathrm{m}^{2} /\right.$ day, days $\left.1-7\right)$ and idarubicin $\left(13 \mathrm{mg} / \mathrm{m}^{2} /\right.$ day, days $\left.1-3\right) \cdot{ }^{14} \mathrm{Her}$ clinical course was notable for mild mucositis, fluctuating blood sugars, and culture-negative neutropenic fever. A bone marrow aspirate and biopsy obtained on day 14 was markedly hypocellular; a repeat bone marrow biopsy on day 28 was normocellular, with maturing trilineage 


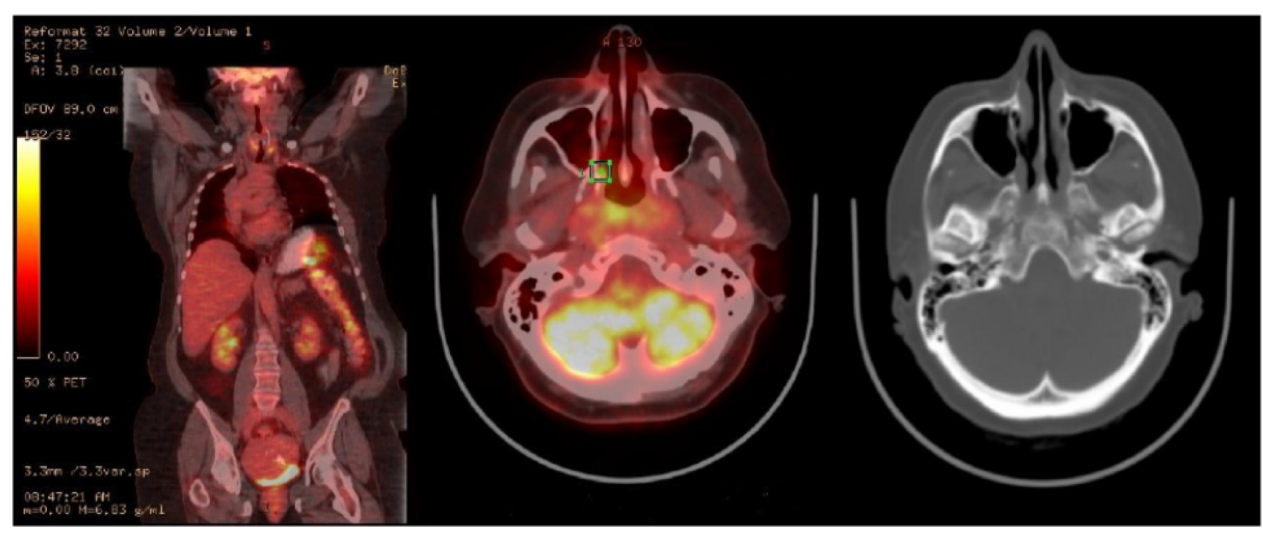

Figure 2 PET-CT scan showed inflammatory changes in the nasopharynx.

Abbreviations: $\mathrm{CT}$, computed tomography; PET, positron emission tomography.

hematopoiesis and no residual leukemia. She went on to receive an additional three cycles of consolidation therapy, with continuous infusion cytarabine and bolus idarubicin (5+2 regimen). ${ }^{14}$ She remains in remission, with a normal CBC at the 18-month follow-up visit.

\section{Discussion and literature review}

GS is an infrequently diagnosed condition. It is reported in about $2.5 \%-9.1 \%$ of patients with AML. ${ }^{15-17}$ While it can be solitary or multifocal, most cases manifest as isolated single lesions. ${ }^{1}$ The most common sites of EM involvement of AML include the skin (leukemia cutis), lymph node, and bone, but other sites, including the female reproductive tract, breast, gut, and testis have been reported. In the head and neck region, GS will usually involve the orbits, and only rarely will it affect the nasopharynx. ${ }^{18}$ Utilizing a MEDLINE $^{\circledR} / \mathrm{PubMed}^{\mathbb{R}}$ search, with the key words "granulocytic/myeloid sarcoma," "chloroma," "nasopharynx," and "acute myeloid leukemia" and restricting our search to the English language reports between the years 2000-2013, we identified 13 additional patients between the ages of 1 to 81 years (median age of 37 years) with GS involving the nasopharynx (Table 1)..$^{419-30}$ The male to female ratio within the group was $1: 1$. Sinonasal congestion or hearing loss was the reason why most patients sought medical attention. The longest reported disease-free interval from diagnosis was 36 months. ${ }^{4,22}$ Among the seven cases where the disease-free interval was reported, the median was 18 months (range, 4 to 36 months).

In the absence of circulating myeloblasts, GS is seldom considered in the initial differential diagnosis of a soft tissue mass. ${ }^{10,12}$ Its similarity, both radiographically and histopathologically, to other small round cell tumors, such as lymphoblastic leukemia, melanoma, Ewing sarcoma, blastic plasmacytoid dendritic cell neoplasm, as well as certain forms of non-Hodgkin lymphoma and benign EM hematopoiesis means that there may be a delay in diagnosis while the clinician waits for supportive diagnostic tests from the pathologist. ${ }^{31}$ GS typically consists of a diffuse and infiltrative population of myeloblasts and granulocytic cell types. Infrequently, tumors can occur in the setting of trilineage hematopoiesis or erythroid or megakaryocytic precursors, particularly in cases of transformation from MPN. Immunohistochemistry is useful for establishing the diagnosis of GS and can be easier to perform than flow cytometry, which requires fresh tissue. ${ }^{32}$ Immunohistochemical markers, such as CD68, MPO, lysozyme, and CD43, can assist in differentiating between myeloid and nonmyeloid cells. ${ }^{1}$ Myelocytic differentiation may also be confirmed by Leder stain (chloroacetate esterase). ${ }^{17} \mathrm{CD} 117, \mathrm{CD} 34$, and terminal deoxynucleotidyl transferase (TdT) are useful as markers of immaturity. When GS is found in an EM location and in the absence of circulating blasts, a bone marrow biopsy is necessary to rule out concurrent marrow involvement. Cytogenetic abnormalities are seen in roughly $50 \%$ of cases and include monosomy 7 , trisomy $8, \operatorname{inv}(16), \mathrm{t}(9 ; 11)$, deletion (del)(16q), $\mathrm{t}(8 ; 16)$, and $\mathrm{t}(1 ; 11) .{ }^{1,32-37}$ Nucleophosmin (NPM1) mutations have been reported in $15 \%$ and FMS-related tyrosine kinase 3 (FLT 3) gene mutations in $20 \%-30 \%$ of GS cases ${ }^{38,39}$ however, the clinical significance of NPM1 and FLT3 mutation in this clinical context remains uncertain. ${ }^{38,39}$

A CT scan is best for evaluating soft tissue GS, and magnetic resonance imaging (MRI) with gadolinium is preferred when GS involves the central nervous system. ${ }^{40,41}$ A PET scan may be helpful for detecting additional sites of EM AML and also for planning local (eg, radiotherapy) treatment and/or systemic chemotherapy. ${ }^{42}$ It can also be used for monitoring the response to treatment. ${ }^{32}$ For patients who achieve a complete remission with treatment, the 
Table I Case reports of granulocytic sarcoma involving the nasopharynx

\begin{tabular}{|c|c|c|c|c|c|}
\hline Reference & $\begin{array}{l}\text { Age (years), } \\
\text { sex }\end{array}$ & Clinical features & Associated diagnosis & Cytogenetics & Outcome \\
\hline $\begin{array}{l}\text { Bassichis } \\
\text { et } \mathrm{al}^{21}\end{array}$ & I, male & Masseter muscle & Synchronous AML & NR & Died during chemotherapy \\
\hline $\begin{array}{l}\mathrm{Au} \\
\text { et } \mathrm{al}^{22}\end{array}$ & 37 , male & $\begin{array}{l}\text { Conductive hearing loss, } \\
\text { infiltrative nasopharyngeal } \\
\text { mass }\end{array}$ & Solitary site of GS & Normal & $\begin{array}{l}\text { IFRT and chemotherapy. } \\
\text { CR at } 3 \text { years }\end{array}$ \\
\hline $\begin{array}{l}\text { Nayak } \\
\text { et } \mathrm{al}^{23}\end{array}$ & 24, female & $\begin{array}{l}\text { Bilateral parotid and } \\
\text { nasopharyngeal mass }\end{array}$ & Solitary site of GS & NR & $\begin{array}{l}\text { Patient died on } 17 \text { th day } \\
\text { of chemotherapy, due to } \\
\text { systemic infection }\end{array}$ \\
\hline $\begin{array}{l}\text { Geisse } \\
\text { et a }\left.\right|^{24}\end{array}$ & 60 , male & $\begin{array}{l}\text { Waldeyer's ring } \\
\text { lymphadenopathy }\end{array}$ & Synchronous MDS & NR & Diagnosis made on autopsy \\
\hline $\begin{array}{l}\text { Prades } \\
\text { et } \mathrm{al}^{25}\end{array}$ & 20 , female & $\begin{array}{l}\text { Sinonasal obstruction; right } \\
\text { maxillary and sphenoid } \\
\text { sinus mass }\end{array}$ & $\begin{array}{l}\text { GS of the nasal cavity } \\
\text { and paranasal sinus }\end{array}$ & $\mathrm{t}(19: 1)$ & $\begin{array}{l}\text { AHSCT following } \\
\text { chemotherapy; CR at } \\
\text { I8 months }\end{array}$ \\
\hline $\begin{array}{l}\text { Ozcelik } \\
\text { et } \mathrm{al}^{26}\end{array}$ & 37 , male & $\begin{array}{l}\text { Vocal cord paralysis, } \\
\text { involvement of } 9 \text { th, } 10 \text { th, } \\
\text { and } 12 \text { th cranial nerves }\end{array}$ & $\begin{array}{l}\text { AML (M0) } 6 \text { months } \\
\text { earlier - treated with } \\
\text { chemotherapy to CR }\end{array}$ & NR & $\begin{array}{l}\text { Treated with chemotherapy } \\
\text { with partial regression of } \\
\text { the nasopharyngeal masses; } \\
\text { patient died on } 17 \text { th day } \\
\text { of chemotherapy due to } \\
\text { pulmonary infection }\end{array}$ \\
\hline $\begin{array}{l}\text { Sugimoto } \\
\text { et } \mathrm{al}^{27}\end{array}$ & 31 , female & $\begin{array}{l}\text { Nasopharynx, external } \\
\text { acoustic meatus }\end{array}$ & $\begin{array}{l}\text { AML (M2) } 3 \text { months } \\
\text { earlier - treated with } \\
\text { chemotherapy to CR }\end{array}$ & $\mathrm{t}(8 ; 2 \mathrm{I})(\mathrm{q} 22 ; \mathrm{q} 22)$ & $\begin{array}{l}\text { Achieved CR2 with IFRT, } \\
\text { reinduction chemotherapy, } \\
\text { followed by AHSCT }\end{array}$ \\
\hline $\begin{array}{l}\text { Imamura } \\
\text { et } \mathrm{al}^{4}\end{array}$ & 7, female & $\begin{array}{l}\text { Waldeyer's ring and cervical } \\
\text { lymphadenopathy }\end{array}$ & $\begin{array}{l}\text { Synchronous juvenile } \\
\text { myelomonocytic } \\
\text { leukemia }\end{array}$ & $\begin{array}{l}\mathrm{t}(9 ; 12) \\
(\mathrm{p} 22 ; q 24.1)\end{array}$ & $\begin{array}{l}\text { AHSCT following } \\
\text { chemotherapy; CR at } \\
3 \text { years }\end{array}$ \\
\hline Ferri et $\mathrm{a}^{28}$ & 72 , female & $\begin{array}{l}\text { Right facial swelling and } \\
\text { fever; maxilla-ethmoidal } \\
\text { mass }\end{array}$ & $\begin{array}{l}\text { AML (M0) I year earlier - } \\
\text { treated with hydroxyurea }\end{array}$ & NR & $\begin{array}{l}\text { Best supportive care } \\
\text { only; died after } 10 \text { days of } \\
\text { hospitalization }\end{array}$ \\
\hline $\begin{array}{l}\text { Teramoto } \\
\text { et } \mathrm{al}^{29}\end{array}$ & 81 , female & Nasopharyngeal mass & $\begin{array}{l}\text { Developed AML (M2) } \\
\text { I year later }\end{array}$ & $\begin{array}{l}\text { Complex genomic } \\
\text { defects on cDNA } \\
\text { microarray }\end{array}$ & $\begin{array}{l}\text { Radiation therapy only } \\
\text { for GS; chemotherapy for } \\
\text { AML; died } 6 \text { months after } \\
\text { diagnosis of AML }\end{array}$ \\
\hline $\begin{array}{l}\text { Selvarajan } \\
\text { et } \mathrm{al}^{19}\end{array}$ & 25 , male & $\begin{array}{l}\text { Dysphagia, hoarseness, } \\
\text { facial nerve palsy }\end{array}$ & $\begin{array}{l}\text { AML (M2) } 4 \text { years } \\
\text { earlier - treated with } \\
\text { chemotherapy to CR, } \\
\text { followed by AHSCT }\end{array}$ & $\mathrm{t}(8: 21)$ & $\begin{array}{l}\text { Treated with chemotherapy } \\
\text { but had systemic relapse } \\
\text { I year later }\end{array}$ \\
\hline Cho et $\mathrm{al}^{30}$ & I8, male & $\begin{array}{l}\text { Conductive hearing loss, } \\
\text { infiltrative nasopharyngeal } \\
\text { mass }\end{array}$ & Synchronous AML & $R U N X I-R U N X I T I$ & $\begin{array}{l}\text { Recurrence after } 7 \text { months } \\
\text { of chemotherapy; achieved } \\
\text { CR2 with reinduction } \\
\text { chemotherapy, followed by } \\
\text { AHSCT }\end{array}$ \\
\hline Mei et $\mathrm{al}^{20}$ & 56, female & Left maxillary sinus & Solitary site of GS & NR & $\begin{array}{l}\text { Surgical resection followed } \\
\text { by chemotherapy; CR at } \\
4 \text { months }\end{array}$ \\
\hline $\begin{array}{l}\text { (Current) } \\
\text { case }\end{array}$ & 63 , female & $\begin{array}{l}\text { Conductive hearing loss, } \\
\text { infiltrative nasopharyngeal } \\
\text { mass }\end{array}$ & $\begin{array}{l}\text { Developed AML } \\
\text { I year later }\end{array}$ & Normal & $\begin{array}{l}\text { Radiation therapy only for } \\
\text { GS; chemotherapy for AML; } \\
\text { CR at } 18 \text { months }\end{array}$ \\
\hline
\end{tabular}

Abbreviations: AHSCT, allogeneic hematopoietic stem cell transplant; AML, acute myeloid leukemia; cDNA, complementary deoxyribonucleic acid; CR, complete remission; CR2, second CR; GS, granulocytic sarcoma; IFRT, involved-field radiotherapy; MDS, myelodysplastic syndrome; NR, not reported; t, translocation.

role of routine monitoring with radiographs has not been established. $^{32}$

The treatment of GS depends upon patient and disease characteristics. The patient's age, associated medical comorbidities, clinical symptoms, tumor karyotype, stage, and the extent of disease are important factors to be considered before planning treatment. There are no randomized studies to help guide the treatment choices, and the GS location does not appear to impact survival. Chemotherapy (both systemic and intrathecal), radiation therapy, surgical extirpation, or any 
combination of these interventions have all been employed (Table 2). Remission-induction chemotherapy similar to that used for AML is favored for either isolated GS or GS presenting with concomitant AML. ${ }^{43,44}$ Significantly longer disease-free intervals without leukemia have been achieved in patients with isolated GS who received systemic chemotherapy rather than surgery or radiation therapy, belying the fact that this is inevitably the first manifestation of a systematic disease. ${ }^{45,46}$ Surgery is generally reserved for cases with acute symptoms (eg, pain, acute nerve compression), and at times, to obtain an adequate tissue sample following a nondiagnostic fine-needle aspiration.

The role of allogeneic hematopoietic stem cell transplantation (AHSCT) in patients with GS has not been studied prospectively, but improved outcomes with AHSCT have been reported in repeated retrospective analyses. ${ }^{1,47}$ In a retrospective study of 51 patients with GS, either isolated or associated with AML, the 5-year overall survival was $48 \%$, with no significant differences in outcomes between the two presentations. ${ }^{48}$ For those patients with GS and graft-versus-host disease, there was a trend toward improved overall survival.

Patients with a history of GS are at risk for relapse, and careful assessments at follow-up appointments are needed as early isolated GS can be asymptomatic. ${ }^{49} \mathrm{~A}$ biopsy of any new or suspicious soft tissue or skin abnormality should be performed, and if no circulating blasts are present, a bone marrow biopsy is necessary. ${ }^{32}$ For patients who relapse after chemotherapy, reinduction chemotherapy may be an option if there has been a long disease-free interval after the

Table 2 Treatment approaches for granulocytic sarcoma

\begin{tabular}{|c|c|}
\hline Disease status & $\begin{array}{l}\text { Suggested treatment } \\
\text { approach }\end{array}$ \\
\hline Isolated GS & $\begin{array}{l}\text { Chemotherapy followed by } \\
\text { surgery/radiation treatment }\end{array}$ \\
\hline GS with bone marrow involvement & $\begin{array}{l}\text { Chemotherapy with } \\
\text { consideration for AHSCT }\end{array}$ \\
\hline Relapsed isolated GS after & Chemotherapy followed by \\
\hline chemotherapy & AHSCT \\
\hline Relapsed GS and bone marrow disease & Chemotherapy followed by \\
\hline after chemotherapy & AHSCT \\
\hline Relapse of isolated GS after AHSCT & $\begin{array}{l}\text { Donor lymphocyte infusion, } \\
\text { tapering of immuno- } \\
\text { suppression if tolerated, or } \\
\text { investigational agents versus } \\
\text { palliative IFRT }\end{array}$ \\
\hline $\begin{array}{l}\text { Relapse of concurrent GS and bone } \\
\text { marrow disease after AHSCT }\end{array}$ & $\begin{array}{l}\text { Investigational agents versus } \\
\text { best supportive care }\end{array}$ \\
\hline
\end{tabular}

Abbreviations: AHSCT, allogeneic hematopoietic stem cell transplant; GS, granulocytic sarcoma; IFRT, involved-field radiotherapy. initial treatment. For those individuals who are deemed hardy enough and who have an identified HLA match, AHSCT is the preferred consolidative approach. When bone marrow and EM relapse occurs synchronously after AHSCT, survival is very poor and no standard treatment has proven effective, although donor lymphocyte infusions, tapering of immunosuppression, or investigational agents may be considered..$^{50,51}$

\section{Disclosure}

The authors report no conflicts of interest in this work.

\section{References}

1. Pileri SA, Ascani S, Cox MC, et al. Myeloid sarcoma: clinicopathologic, phenotypic and cytogenetic analysis of 92 adult patients. Leukemia. 2007;21(2):340-350.

2. King A. A case of chloroma. Monthly J Med. 1853;17:97.

3. Kasahara S, Tsurumi H, Hara T, Goto H, Moriwaki H. Idiopathic myelofibrosis developing isolated granulocytic sarcoma with der $(1 ; 7)(\mathrm{q} 10$; p10) after splenectomy and finally transforming to acute myelogenous leukemia. Leuk Lymphoma. 2000;39(3-4):427-433.

4. Imamura T, Matsuo S, Yoshihara T, et al. Granulocytic sarcoma presenting with severe adenopathy (cervical lymph nodes, tonsils, and adenoids) in a child with juvenile myelomonocytic leukemia and successful treatment with allogeneic bone marrow transplantation. Int J Hematol. 2004;80(2):186-189.

5. Hancock JC, Prchal JT, Bennett JM, Listinsky CM. Trilineage extramedullary myeloid cell tumor in myelodysplastic syndrome. Arch Pathol Lab Med. 1997;121(5):520-523.

6. Cho-Vega JH, Medeiros LJ, Prieto VG, Vega F. Leukemia cutis. Am J Clin Pathol. 2008;129(1):130-142.

7. Eshghabadi M, Shojania AM, Carr I. Isolated granulocytic sarcoma: report of a case and review of the literature. J Clin Oncol. 1986;4(6):912-917.

8. Meis JM, Butler JJ, Osborne BM, Manning JT. Granulocytic sarcoma in nonleukemic patients. Cancer. 1986;58(12):2697-2709.

9. Paydas S, Zorludemir S, Ergin M. Granulocytic sarcoma: 32 cases and review of the literature. Leuk Lymphoma. 2006;47(12):2527-2541.

10. Krause JR. Granulocytic sarcoma preceding acute leukemia: a report of six cases. Cancer. 1979;44(3):1017-1021.

11. Ohanian M, Borthakur G, Quintas-Cardama A, et al. Ocular granulocytic sarcoma: a case report and literature review of ocular extramedullary acute myeloid leukemia. Clin Lymphoma Myeloma Leuk. 2013;13(1):93-96.

12. Byrd JC, Edenfield WJ, Shields DJ, Dawson NA. Extramedullary myeloid cell tumors in acute nonlymphocytic leukemia: a clinical review. J Clin Oncol. 1995;13(7):1800-1816.

13. García-Arpa M, Rodríguez-Vázquez M, Murillo Lázaro C, Calle Primo C. [Myeloid sarcoma in the area of a skin flap]. Actas Dermosifiliogr. 2011;102(9):737-739. Spanish.

14. Wiernik PH, Banks PL, Case DC Jr, et al. Cytarabine plus idarubicin or daunorubicin as induction and consolidation therapy for previously untreated adult patients with acute myeloid leukemia. Blood. 1992;79(2):313-319.

15. Wiernik PH, Serpick AA. Granulocytic sarcoma (chloroma). Blood. 1970;35(3):361-369.

16. Liu PI, Ishimaru T, McGregor DH, Okada H, Steer A. Autopsy study of granulocytic sarcoma (chloroma) in patients with myelogenous leukemia, Hiroshima-Nagasaki 1949-1969. Cancer. 1973;31(4):948-955.

17. Neiman RS, Barcos M, Berard C, et al. Granulocytic sarcoma: a clinicopathologic study of 61 biopsied cases. Cancer. 1981;48(6): $1426-1437$. 
18. Noh BW, Park SW, Chun JE, Kim JH, Kim HJ, Lim MK. Granulocytic sarcoma in the head and neck: CT and MR imaging findings. Clin Exp Otorhinolaryngol. 2009;2(2):66-71.

19. Selvarajan S, Subramanian S, Thulkar S, Kumar L. Granulocytic sarcoma of nasopharynx with perineural spread along the trigeminal nerve. Neurol India. 2008;56(2):210-212.

20. Mei KD, Lin YS, Chang SL. Myeloid sarcoma of the cheek and the maxillary sinus regions. J Chin Med Assoc. 2013;76(4):235-238.

21. Bassichis B, McClay J, Wiatrak B. Chloroma of the masseteric muscle. Int J Pediatr Otorhinolaryngol. 2000;53(1):57-61.

22. Au WY, Kwong YL, Ho WK, Shek TW. Primary granulocytic sarcoma of the nasopharynx. Am J Hematol. 2001;67(4):273-274.

23. Nayak DR, Balakrishnan R, Raj G, Pillai S, Rao L, Manohar C. Granulocytic sarcoma of the head and neck: a case report. Am J Otolaryngol. 2001;22(1):80-83.

24. Geisse M, Mall G, Fritze D, Gartenschläger M. [Granulocytic sarcoma of the tonsils associated with myelodysplastic syndrome]. Dtsch Med Wochenschr. 2002;127(50):2673-2676. German.

25. Prades JM, Alaani A, Mosnier JF, Dumollard JM, Martin C. Granulocytic sarcoma of the nasal cavity. Rhinology. 2002;40(3):159-161.

26. Ozçelik T, Ali R, Ozkalemkaş F, et al. A case of granulocytic sarcoma during complete remission of acute myeloid leukemia with multiple masses involving the larynx and nasopharynx. Kulak Burun Bogaz Ihtis Derg. 2003;11(6):183-188.

27. Sugimoto Y, Nishii K, Sakakura M, et al. Acute myeloid leukemia with $\mathrm{t}(8 ; 21)(\mathrm{q} 22 ; \mathrm{q} 22)$ manifesting as granulocytic sarcomas in the rhinopharynx and external acoustic meatus at relapse after high-dose cytarabine: case report and review of the literature. Hematol J. 2004;5(1):84-89.

28. Ferri E, Minotto C, Ianniello F, Cavaleri S, Armato E, Capuzzo P. Maxillo-ethmoidal chloroma in acute myeloid leukaemia: case report. Acta Otorhinolaryngol Ital. 2005;25(3):195-199.

29. Teramoto H, Miwa H, Patel V, et al. Gene expression changes in a patient presenting nonleukaemic nasal granulocytic sarcoma to acute myelogenous leukaemia using $40 \mathrm{~K}$ cDNA microarray. Clin Lab Haematol. 2006;28(4):262-266.

30. Cho SF, Liu YC, Tsai HJ, Lin SF. Myeloid sarcoma mimicking nasopharyngeal carcinoma. J Clin Oncol. 2011;29(25):e706-e708.

31. Ngu IW, Sinclair EC, Greenaway S, Greenberg ML. Unusual presentation of granulocytic sarcoma in the breast: a case report and review of the literature. Diagn Cytopathol. 2001;24(1):53-57.

32. Bakst RL, Tallman MS, Douer D, Yahalom J. How I treat extramedullary acute myeloid leukemia. Blood. 2011;118(14):3785-3793.

33. Swerdlow SH, Campo E, Harris NL, et al. WHO Classification of Tumours of Haematopoietic and Lymphoid Tissues. 4th ed. Lyon: IARC Press; 2008;2.

34. Zhang XH, Zhang R, Li Y. Granulocytic sarcoma of abdomen in acute myeloid leukemia patient with inv(16) and $\mathrm{t}(6 ; 17)$ abnormal chromosome: case report and review of literature. Leuk Res. 2010;34(7):958-961.

35. Hagemeijer A, Hählen K, Sizoo W, Abels J. Translocation (9;11) (p21;q23) in three cases of acute monoblastic leukemia. Cancer Genet Cytogenet. 1982;5(2):95-105.
36. Dachary D, Bernard P, Lacombe F, et al. Acute myeloid leukemia with marrow hypereosinophilia and chromosome 16 abnormality. Cancer Genet Cytogenet. 1986;20(3-4):241-246.

37. Bernstein R, Pinto MR, Spector I, Macdougall LG. A unique 8; 16 translocation in two infants with poorly differentiated monoblastic leukemia. Cancer Genet Cytogenet. 1987;24(2):213-220.

38. Falini B, Lenze D, Hasserjian R, et al. Cytoplasmic mutated nucleophosmin (NPM) defines the molecular status of a significant fraction of myeloid sarcomas. Leukemia. 2007;21(7):1566-1570.

39. Ansari-Lari MA, Yang CF, Tinawi-Aljundi R, et al. FLT3 mutations in myeloid sarcoma. Br J Haematol. 2004;126(6):785-791.

40. Fritz J, Vogel W, Bares R, Horger M. Radiologic spectrum of extramedullary relapse of myelogenous leukemia in adults. AJR Am J Roentgenol. 2007;189(1):209-218.

41. Kook H, Hwang TJ, Kang HK, Kim SH, Kim JH. Spinal intramedullary granulocytic sarcoma: magnetic resonance imaging. Magn Reson Imaging. 1993;11(1):135-137.

42. Stölzel F, Röllig C, Radke J, et al. ${ }^{18}$ F-FDG-PET/CT for detection of extramedullary acute myeloid leukemia. Haematologica. 2011;96(10): $1552-1556$

43. Tsimberidou AM, Kantarjian HM, Estey E, et al. Outcome in patients with nonleukemic granulocytic sarcoma treated with chemotherapy with or without radiotherapy. Leukemia. 2003;17(6):1100-1103.

44. Lan TY, Lin DT, Tien HF, Yang RS, Chen CY, Wu K. Prognostic factors of treatment outcomes in patients with granulocytic sarcoma. Acta Haematol. 2009;122(4):238-246.

45. Yamauchi K, Yasuda M. Comparison in treatments of nonleukemic granulocytic sarcoma: report of two cases and a review of 72 cases in the literature. Cancer. 2002;94(6):1739-1746.

46. Imrie KR, Kovacs MJ, Selby D, et al. Isolated chloroma: the effect of early antileukemic therapy. Ann Intern Med. 1995;123(5): 351-353.

47. Avni B, Rund D, Levin M, et al. Clinical implications of acute myeloid leukemia presenting as myeloid sarcoma. Hematol Oncol. 2012;30(1):34-40.

48. Chevallier P, Mohty M, Lioure B, et al. Allogeneic hematopoietic stem-cell transplantation for myeloid sarcoma: a retrospective study from the SFGM-TC. J Clin Oncol. 2008;26(30):4940-4943.

49. Michel G, Boulad F, Small TN, et al. Risk of extramedullary relapse following allogeneic bone marrow transplantation for acute myelogenous leukemia with leukemia cutis. Bone Marrow Transplant. 1997;20(2): 107-112.

50. Békássy AN, Hermans J, Gorin NC, Gratwohl A. Granulocytic sarcoma after allogeneic bone marrow transplantation: a retrospective European multicenter survey. Acute and Chronic Leukemia Working Parties of the European Group for Blood and Marrow Transplantation. Bone Marrow Transplant. 1996;17(5):801-808.

51. Szer J. The prevalent predicament of relapsed acute myeloid leukemia. Hematology Am Soc Hematol Educ Program. 2012;2012:43-48.
International Medical Case Reports Journal

\section{Publish your work in this journal}

The International Medical Case Reports Journal is an international, peer-reviewed open-access journal publishing original case reports from all medical specialties. Previously unpublished medical posters are also accepted relating to any area of clinical or preclinical science. Submissions should not normally exceed 2,000 words or
Dovepress

4 published pages including figures, diagrams and references. The manuscript management system is completely online and includes a very quick and fair peer-review system, which is all easy to use. Visit http://www.dovepress.com/testimonials.php to read real quotes from published authors. 